\title{
The Effect of Citrus lemon Aromatherapy on Emesis Gravidarum Patient
}

\author{
Bunga Tiara Carolin*, Siti Syamsiah, Rian Yuniati \\ National University, Jakarta, Indonesia \\ *bunga.tiara@civitas.unas.ac.id
}

\begin{abstract}
Emesis Gravidarum is a natural and frequent symptom occurred on pregnant mothers in their first trimester. Nausea usually occurs in the morning. It also can occur all the time and in the evening. This symptom usually occurs for six weeks from the first day of last menstruation day for about 10 weeks. In 2018, the emesis gravidarum case in Lampung Province on pregnant mothers reached $50-90 \%$, while hyperemesis gravidarum reached $10-15 \%$ from the total pregnant mothers at that time which was 168,098 pregnant mothers. This research aimed to know the effect of citrus lemon aromatherapy on patients with emesis gravidarum in BPM Titik Apriliana of South Lampung. This quasiexperimental research was done through One Group Pretest-Posttest Design. Samples were taken using total sampling which was 30 pregnant mothers in their first trimester experiencing nausea. The measurement tool used in this research was PUQE. The normality test of this research was carried out by using the skewness and kurtosis value in which it resulted in normal distribution so that the statistical test used was Paired Ttest. The research found that the average of morning sickness level during the pretest was 9.57 while after the intervention it decreased to 6.40. In addition, the statistical result obtained was $\mathrm{p}=0.000$. It can be concluded that the provision of citrus lemon aromatherapy can affect the patients with emesis gravidarum. In addition, it is suggested that the community can make citrus lemon aromatherapy as an alternative method to decrease emesis gravidarum in the first trimester of pregnant mothers..
\end{abstract}

Keywords : Aromatherapy, Citrus Lemon, Emesis Gravidarum, First Trimester, Pregnant Mother. 


\section{STRADA Jurnal Ilmiah Kesehatan}

DOI: $10.30994 /$ sjik.v9i2.340

ISSN: 2252-3847 (print); 2614-350X (online)

Vol.9 No.2 November 2020 Page.599-604

\section{BACKGROUND}

Pregnancy is a sustainable link and consists of ovulation, spermatozoa and ovum migration, conception and zygote growth, nidation (implantation) in uterus, placenta formation and conception result development until the full term (Manuaba, 2010). Emesis Gravidarum is a natural and frequent symptom occurred on pregnant mothers in which the pregnant mothers will experience morning sickness almost every morning and evening. This symptom occurs for about 6 weeks from the first day of last menstruation day for about 10 weeks. Morning sickness occurs on $60-80 \%$ of primigravida. This symptom becomes worse in one of thousand pregnancy (Prawirohardjo, 2014).

Morning sickness usually occurs in the morning, but also can happen all the time. A previous study approximated that morning sickness occurs in 50-90\% of pregnancy. Morning sickness starts at pregnancy age of 9-10 weeks with complaining peak at $11-13^{\text {th }}$ week. In $1-10 \%$ of pregnancy, the symptom can continue until $20-22^{\text {nd }}$ week (Baliknova \& Budgoza, 2014). morning sickness in pregnancy has significant effect on the body in which the mother becomes very weak, having pale face and experiences significant decrease of urination so that the body fluids decreases and blood becomes thick (hemoconcentration). Such condition slow down the blood circulation so that the oxygen and food supply to the tissue also decreases. Thus, it can cause tissue damage which can endanger the mother and fetus (Rofiah, 2019)

World Health Organization (WHO) 2015, issued that the number of hyperemesis gravidarum cases reached $12.5 \%$ from all pregnancy cases in the world. The statistical data issued by WHO as United Nations agency which handles health issue recorded that the mortality rate of mothers during pregnancy and labor reached 515 thousands annually (WHO, 2015). WHO estimated that there was 500,000 mothers died annually due to the direct effect of pregnancy (WHO, 2015). The number of hyperemesis gravidarum case in Indonesia in 2016 reached 1.5-3\% of pregnant mothers (Ministry of Health of RI, 2016).

Maternal Mortality Rate in South Lampung District in 2017 was 52.68 per 100,000 KH (11 cases) in which previously in 2016 was 74 per 100,000 KH (15 cases). In addition the achievement of maternal mortality rate in South Lampung District in 2013 was always below the target (Health Profile of South Lampung District, 2017). The number of emesis gravidarum cases on pregnant mothers reached 50-90\%, while hyperemesis gravidarum cases reached $10-15 \%$ of the total pregnant mothers in Lampung Province which was 168,098 pregnant mothers (Health Agency, Lampung Province, 2018).

There are several medicinal plants that can reduce emesis gravidarum such as Ginger Oil and citrus lemon (Maternity, 2017; Carolin \& Ummah, 2019). Citrus lemon is one of essential oils frequently used by pregnant mothers as it is regarded as safe medicine for pregnancy. According to previous study, as much as $40 \%$ women had used citrus lemon aroma to ease morning sickness, and $26.5 \%$ of them chose it as effective method in controlling morning sickness symptom. Since it increases the interest in using herbs on pregnancy, citrus lemon is available in all seasons and used by Iran community (Maternity, 2017).

Citrus lemon aromatherapy is essential oil produced from citrus lemon often used in aromatherapy. Citrus aroma therapy is a type of aromatherapy which is safe for pregnancy and labor (Medforth, et al., 2013). Young (2011) stated that citrus lemon essential oil contains limonene 66-80\%, geranil acetate, nerol, linalil acetate, $\beta$ pinene $0.4-15 \%, \alpha$ pinene $1-4 \%$, terpinene $6-14 \%$ and myrcen. Chemical compounds such as geranil acetate, nerol, and linalil acetate, have antidepressant, antiseptic, antispasmodic, sexual arousal enhancer and light sedative (Namazi, et al, 2014). Citrus lemon aromatherapy has content 


\section{STRADA Jurnal Ilmiah Kesehatan}

DOI: $10.30994 /$ sjik.v9i2.340

ISSN: 2252-3847 (print); 2614-350X (online)

Vol.9 No.2 November 2020 Page.599-604

which can kill meningococcus and typhus bacteria, has antifungal effect and effective in producing anti-anxiety, anti-depressant, anti-stress and helps to increasing and focusing thought (Saridewi \& Safitri, 2018). Citrus lemon aromatherapy is herbs oil that mostly used and considered as safe medicine for pregnancy (Vitrianingsih \& Khadijah, 2019).

According to research conducted by Wardani, et al (2019) at the average, morning sickness in first trimester pregnant mothers obtained INVR value of 17.67 which was in heavy morning sickness category. However, when the mothers were given citrus lemon aromatherapy, the INVR value decreased to 11.53 which was in mild morning sickness category. This research result also indicated that citrus lemon aromatherapy affects the emesis gravidarum on first trimester pregnant mothers.

BPM Titik is one of village midwives working in the area of South Lampung District. Based on the preliminary survey conducted, there was 20 pregnant mothers who experienced morning sickness, and it was found that they used medicine to decrease the morning sickness. This encourages the researchers to conduct research in the use of Citrus lemon aromatherapy to decrease morning sickness.

\section{METHODS}

This quasi-experimental research was done through one group pretest-posttest design. The research was carried out in November 2019-January 2020 in Independent Midwifery Practice (Bidan Praktik Mandiri) of Titik Apriliana, South Lampung. The population selected in this research was all first trimester pregnant mothers experiencing morning sickness symptom. The total samples involved in this research was 30 pregnant mothers choosing using total sampling. The current research used Pregnancy-Unique Quantification of Emesis and Nausea (PUQE) sheet as the measurement tool. Material used in this research was Citrus lemon aromatherapy using tissue that has been given by 3 drops of citrus lemon and inhaled for 5 minutes and repeated for twice a day for 7 days. The normality test of this research was done by seeing the skewness and kurtosis value where the result was distributed normally so that the statistical result used was Paired $T$ test.

\section{RESULTS}

Table 1

Frequency Distribution of Respondents Based on Age and Parity

\begin{tabular}{lcc}
\hline \multicolumn{1}{c}{ Variable } & Frequency & Percentage \\
\hline Age & & \\
$<20$ years old & 5 & 16.7 \\
20 - 35 years old & 19 & 63.3 \\
$>35$ years old & 6 & 20.0 \\
\hline Parity & & \\
Primipara & 13 & 43.3 \\
Multipara & 11 & 36.7 \\
Grandepara & 6 & 20.0 \\
\hline
\end{tabular}

Based on table 1, it indicates that among 30 respondents involved, most of them were at the age of 20-35 years old by 19 (63.3\%) mothers and most of them were categorized in primipara group by $13(43.4 \%)$ mothers. 


\section{Table 2}

Difference of Average in Before and After Intervention on First Trimester Pregnant Mothers

Table 2 shows that there was difference in the average of morning sickness before

\begin{tabular}{|c|c|c|c|c|c|c|}
\hline \multirow[t]{2}{*}{ Variable } & \multicolumn{2}{|c|}{ Pretest } & \multicolumn{2}{|c|}{ Posttest } & \multirow[t]{2}{*}{$t$} & \multirow{2}{*}{$\begin{array}{c}p- \\
\text { value }\end{array}$} \\
\hline & $\mathbf{M}$ & SD & $\mathbf{M}$ & SD & & \\
\hline $\begin{array}{l}\text { The effect of citrus lemon } \\
\text { aromatherapy on Emesis } \\
\text { Gravidarum }\end{array}$ & 9.57 & $\begin{array}{c}3.01 \\
4\end{array}$ & 6.40 & 2.458 & 6.959 & 0.000 \\
\hline
\end{tabular}

the intervention with mean value of 9.57; std deviation of 3.014 and after the intervention of citrus lemon aromatherapy with mean value of 6.40 ; std deviation of 2.458 . It obtained $p$ value of $0.000(\mathrm{p}<0.05)$ which means that there is effect of citrus lemon aromatherapy on emesis gravidarum mothers of pregnant mothers in Di BPM Titik Apriliana, South Lampung 2020.

\section{DISCUSSION}

\section{Respondents' Characteristics}

Mother's age is how long the mother lives since she was born until now. Age is period of new life pattern, in which the more increase the age, the more it reaches reproduction age (Notoatmodjo, 2010). In the current research, most of the respondents were at the age of 20-35 years old by 19 respondents $(63.3 \%)$, followed by respondents at the age of above 35 years old by 6 respondents $(20 \%)$ and 5 respondents $(16.7 \%)$ at the age below 20 years old. Another research project was carried out by Atika, et al (2016) resulting that hyperemesis gravidium case happened more in low risk age category which was $74.2 \%$ compared to high risk age which was $17.3 \%$. morning sickness during pregnancy usually causes by changes in endocrine system during pregnancy, especially caused by the fluctuation of HCG (Human Chrionic Gonadtropin) level, particularly the period of gestational morning sickness occurs at first trimester, where HCG reaches its highest level (Hastuti, 2010).

Parity is mothers that have given birth to full-term baby (Manuaba, 2010). In this research, most respondents' parity was in primipara category which was by 13 respondents $(43.3 \%)$, followed by multipara by 11 respondents $(36.7 \%)$ and grandemultipara by 6 respondents (20\%). Another study done by Atika, et al (2016) found that the parity distribution obtained result that most of mothers in their research were categorized in primipara $(48.7 \%)$ group and there was significant relationship between parity and hyperemesis gravidarum. Hyperemesis Gravidarum usually occurs in primipara because few of them has not yet able to adapt to the increase of estrogen and chorionic gonadotropin hormone so that it causes morning sickness or hyperemesis gravidarum (Fuji, 2012). Hyperemesis gravidarum occurs because the mother has not been able to adapt to the hormone. Physiological factors has essential role in the occurrence of hyperemesis gravidarum. Although it is known yet, whether there is relationship between Hyperemesis Gravidarum and physiological factor (BKKBN, 2012).

\section{The Effect of Citrus Lemon Aromatherapy on Emesis Gravidarum Patients}

Aromatherapy is one of medication or treatment techniques using smells from essential oil (Dewi, Putra, \& Witarsa, 2013). Citrus lemon aromatherapy is a type of aromatherapy which is safe for pregnancy and labor (Medforth, et al, 2013). The main 


\section{STRADA Jurnal Ilmiah Kesehatan}

DOI: $10.30994 /$ sjik.v9i2.340

ISSN: 2252-3847 (print); 2614-350X (online)

Vol.9 No.2 November 2020 Page.599-604

principal of aromatherapy is the utilization of smells from plants or flowers to change the feeling, psychological, spiritual status and physical condition of someone through the relationship between thought and body of the patients (Carstens, 2013). Citrus lemon contains limonen, citral, linalyl, linalool, and terpineol which and stabilize the central nerve system, creating happy feeling, increase appetizer, optimize blood circulation and as sedative (Budiana, 2013). This research obtained the average of morning sickness during the pretest by 9.57 , while after the intervention, it became 6.40 . Statistical test result also obtained that there was effect of citrus lemon aromatherapy on emesis gravidarum patients of pregnant mothers in BPM Titik Apriliana of South Lampung in 2020.

This research result is in line with the research conducted by Maesaroh \& Putri (2019) obtaining that the average frequency of morning sickness before the intervention was 17.37 times, while after the intervention it decreased to 12.43 times. It also obtained that there effect of citrus lemon aromatherapy inhalation on morning sickness of first trimester pregnant mothers ( $\mathrm{p}$ value 0.000). Similar result was obtained by Vitrianingsih \& Khadijah (2019) in which based on Rhodes Index, the morning sickness score on pregnant mothers with emesis gravidarum which was 22.1 and there was decrease in score after the intervention which became 19.8. It was obtained that citrus lemon aromatherapy decreased the morning sickness of pregnant mothers $(\mathrm{p}$-value $=0.017$ ). This research result is also in line with research done by Martenity, et al (2017) that the frequency of morning sickness before inhaling citrus lemon aromatherapy was 24.67, while after the intervention it became 17.87. Thus, there was effect of citrus lemon aromatherapy inhalation on the morning sickness of pregnant mothers by P-value $=0.000$.

It is assumed that there was effect of citrus lemon aromatherapy on emesis gravidarum on first trimester pregnant mothers due to the citrus lemon essential which is one of the safest alternative and mostly used. According to researchers, the decrease of morning sickness is due to the fresh smell of the fruit which can help improve and protect the body. Furthermore, in this research, the pregnant mothers also experienced changes in morning sickness fur to the substances contained in the fruit and the absence of pathological factors experienced by the pregnant mothers. The effect of citrus lemon aromatherapy on emesis gravidarum is because aromatherapy can affect the inhaler including calmness and freshness. Aromatherapy is a therapeutic action by using essential oil which can affect someone's mood so that it can decrease morning sickness.

\section{CONCLUSION}

Based on the research that has been conducted in BPM Titik Apriliana, South Lampung in 2019 in 30 respondents, it can be summed up that there is difference in morning sickness level of first trimester mothers before and after given citrus lemon aromatherapy. It is expected that community can choose citrus lemon aromatherapy as one of alternative methods in decreasing emesis gravidarum on first trimester pregnant mothers.

\section{REFERECES}

Atika, I., Putra, H. K., \& Thaib, S. H. (2016). Hubungan Hiperemesis Gravidarum dengan Usia Ibu, Usia Gestasi, Paritas, dan Pekerjaan pada Pasien Rawat Inap di RSUP Dr. Moh. Hoesin Palembang. Jurnal Kedokteran dan Kesehatan: Publikasi Ilmiah Fakultas Kedokteran Universitas Sriwijaya, 3(3), 166-171.

Balikova M \& Budgoza. (2014) Quality Of Women'S Life With Nausea And Vomiting During Pregnancy. Central European Journal Of Nursing and Midwifery. Vol 5 (1) 


\section{STRADA Jurnal Ilmiah Kesehatan}

DOI: $10.30994 /$ siik.v9i2.340

ISSN: 2252-3847 (print); 2614-350X (online)

Vol.9 No.2 November 2020 Page.599-604

BKKKBN. (2012). Pengaruh Usia Terhadap Kejadian Hiperemesis Gravidarum. http://Pengaruh-Usia-Terhadap-Kejadian-Hiperemesis-Gravidarum.html.

Budiana, N.S. (2013). Buah Ajaib Tumpas Penyakit. Jakarta : Penebar Swadaya

Carolin, B. T., Ummah, A., H. (2019). Pengaruh Pemberian Aromaterapi Ginger Oil (Zingiber officinale) Terhadap Emesis Gravidarum Pada Ibu Hamil Trimester I Di Klinik Makmur Jaya Tahun 2019. Jurnal Kesehatan Qamarul Huda, 7(1), 1-5.

Carstens, J. (2013). Complementary therapies (aromatherapy and herbal medicine) clinician information, Evidense Sumaries-Joanna Briggs Institute, 11. Retrieved from http://search. Proquest. com.

Dewi, N. K. A. S., Putra, P. P., \& Witarsa, I. M. S. (2013). Pengaruh Aromaterapi Inhalasi Terhadap Penurunan Tingkat Kecemasan Pasien Gagal Ginjal Kronik yang Menjalani Hemodialisis di RSUD Wangaya Denpasar. Denpasar: Universitas Udayana.

Dinas Kesehatan Provinsi Lampung, 2018. Profil Kesehatan Propinsi Lampung.

Hartuti, 2010. Panduan Ibu Hamil Melahirkan \& Merawat Bayi. UBA Press

Kementrian Kesehatan Republik Indonesia, 2016.

Maesaroh, S., \& Putri, M. (2019). Inhalasi Aromaterapi Lemon Menurunkan Frekuensi Mual Muntah pada Ibu Hamil. Jurnal Kesehatan Metro Sai Wawai, 12(1), 30-35.

Manuaba. 2010. Pengantar Kuliah Obstetri. Jakarta : EGC.

Manuaba. I. A. C. 2010. Gadar Obstetri \& Ginekologi Sosial Untuk Profesi Bidan. Jakarta : EGC

Maternity, D. (2017). Inhalasi Lemon Mengurangi Mual Muntah pada Ibu Hamil Trimester Satu. Jurnal Ilmiah Bidan, 2(3), 10-15.

Medforth, J., Battersby, S., \& Evans, M. M. B. \& Walker, A.(2013). Kebidanan Oxford dari bidan untuk bidan. Jakarta: Buku Kedokteran EGC.

Namazi, M., Akbari, A.S., Mojab, F.,Talebi, A., Majd, H.A. \& Jannesari,S. (2014) Aromatherapy With Citrus aurantium Oil and Anxiety during the First Stage of Labor. Iranian Journal Of Pharmaceutical Research.

Notoatmodjo, S. (2010). Prinsip-prinsip Dasar Ilmu Kesehatan Masyarakat. Jakarta: Rineka Cipta.

Prawirohardjo, S. (2014) Ilmu Kebidanan. Jakarta: PT Bina Pustaka.

Profil Kesehatan. (2017). Profil Kesehatan Kabupaten Lampung Selatan.

Puji, A., H. (2012). Buku Ajar Asuhan Kebidanan Ibu I (kehamilan). Penerbit Rohima Press. Yogyakarta

Rofi'ah, S. (2019). Studi Fenomologi Kejadian Hiperemesis Gravidarum pada Ibu Hamil Tromester I. Jurnal Riset Kesehatan, Vol 8 (1): 42 - 52

Saridewi, W. (2018). Pengaruh Aromaterapi Lemon terhadap Emesis Gravidarum di Praktik Mandiri Bidan Wanti Mardiwati. Jurnal Ilmu Kesehatan. Vol 17 (03)

Vitrianingsih, V., \& Khadijah, S. (2019). Efektivitas Aroma Terapi Lemon untuk Menangani Emesis Gravidarum. Jurnal Keperawatan, 11(4), 277-284.

Wardani, P. K., Mukhlis, H., \& Pratami, R. (2019). Pengaruh Essensial Lemon Terhadap Emesis Gravidarum pada Ibu Trimester I di Kecamatan Natar Kabupaten Lampung Selatan. Wellness And Healthy Magazine, 1(2), 131-138.

World Health Organization. (2015). Hiperemesis Gravidarum. https://data.worldbank.org di akses tanggal 20 September 2019

Young, G. (2011) Essencial Oil Pocket Reference 5 Th Ed. Amazon : Life Science Pubhlising 